\title{
EDUCAÇÃO E EMANCIPAÇÃO EM KARL MARX E THEODOR ADORNO
}

Carla Michele Ramos Torres ${ }^{1}$

\begin{abstract}
Resumo
Os conceitos são históricos e isso significa compreendê-los à luz do contexto temporal e espacial dos diferentes sujeitos. No intuito de contribuir com o pensamento filosófico da história da educação, o presente artigo analisa a concepção de Educação e Emancipação de Karl Marx e Theodor Adorno, com base em seus próprios escritos. Fundamentado no materialismo histórico dialético, o estudo procura observar a conjuntura histórica de cada intelectual e a relação desta com o pensamento de ambos. Espera-se identificar as principais divergências e similaridades conceituais entre esses teóricos, principalmente no entendimento acerca da educação para a emancipação.
\end{abstract}

Palavras-chave: Educação. Emancipação. Marxismo.

\section{EDUCATION AND EMANCIPATION IN KARL MARX AND THEODOR ADORNO}

\begin{abstract}
The concepts are historical and that means understanding them in light of temporal and spatial context of different subjects. In order to contribute to the philosophical thinking of the history of education, this article analyzes the design of Education and Emancipation of Karl Marx and Theodor Adorno, based on his own writings. Grounded on dialectical and historical materialism, the study seeks to observe the historical conjuncture of each intellectual and its relationship with the thinking of both of them. It is expected to identify the main differences and conceptual similarities between these theoriticians, especially in the understanding of education for emancipation.
\end{abstract}

Keywords: Education. Emancipation. Marxism. 


\section{INTRODUÇÃO}

O papel da educação na sociedade é constantemente discutido por diferentes setores sociais, sendo um tema central nas reflexões contemporâneas relacionadas às políticas públicas e ao pensamento educacional. Seja no universo acadêmico, nos departamentos governamentais e empresariais, discorrer sobre educação tornou-se praxe entre os intelectuais e lideranças políticas e econômicas. Todavia, às vezes a ausência de uma análise teórica mais elaborada e distante da realidade material, promove a difusão e até mesmo um assentimento sem criticidade de noções contraditórias acerca de conceitos, terminologias e historicidade do papel da educação na sociedade de classes.

Amostras dessas concepções são visíveis nos meios de comunicação brasileiros, por meio de uma avalanche de propagandas, notícias, debates e discursos que reiteram a ideia de que a educação é agente primordial na consolidação de uma nação desenvolvida e sem disparidades sociais e econômicas. Um primeiro exemplo a ser citado, foi o discurso de posse presidencial, proferido por Dilma Rousseff, ao defender o lema Brasil Pátria Educadora declarando que a educação seria a prioridade das prioridades em seu segundo mandato. (ROUSSEFF, 2015).

Outro exemplo a ser citado, está nas propagandas e nas ações das Organizações Não Governamentais (ONGs) que também levantam a bandeira da educação como responsável pelas transformações sociais sem aprofundar o debate para além do universo educacional. Essas entidades realizam parcerias com as redes públicas de ensino disseminando a ideia de que lutam por uma educação de qualidade na garantia de um futuro melhor para todas as pessoas. Porém, sabemos que "qualidade" e "um futuro melhor" são conceitos variáveis, pois seus significados expressam a vida concreta daqueles que os pronunciam.

É preciso ressaltar que as ONGs são entidades sem fins lucrativos, mas não devemos esquecer que possuem suas próprias ideologias, uma vez que são constituídas por sujeitos coletivos pertencentes a uma determinada classe social. A partir dessas afirmativas, podemos lançar uma série de questionamentos sobre o papel da educação na sociedade capitalista, mas devido ao conteúdo do presente artigo nos concentraremos somente na seguinte problemática: Qual é o projeto de educação e emancipação que vem de encontro com as necessidades das classes trabalhadoras?

Nossa sociedade é marcada por uma alta concentração de renda na mão de uma minoria; por contradições sociais; pelo avanço de empreendimentos privados na área educacional que concebem a educação prioritariamente na perspectiva da competitividade; pela mistificação da cidadania democrática burguesa e pela carência de uma formação crítica capaz de superar o sistema capitalista. Nessa conjuntura, é imprescindível trazer a tona uma análise mais profunda acerca do conceito de educação e emancipação, no sentido de sustentar teoricamente um projeto de sociedade em que o ser humano seja efetivamente livre de qualquer forma de exploração.

Defendemos que a produção do conhecimento é histórica e está sempre em movimento, portanto, ao trazer à tona formulações teóricas sobre determinados assuntos, o pesquisador não é capaz de abandonar suas condições históricas. Além disso, o historiador 
precisa contextualizar o seu objeto de análise, a fim de evitar anacronismos e perceber tanto as particularidades e a totalidade desse objeto.

No sentido de repensar o papel da educação na sociedade de classes e desmistificar as noções contraditórias que a cercam, o presente artigo objetiva analisar as concepções sobre Educação e Emancipação elaboradas por Karl Marx e Friedrich Engels (século XIX) e Theodor Adorno (século XX). Para isso, procuramos demonstrar as relações dessa interpretação com as condições históricas de cada pensador e destacar as proximidades e as distâncias entre as teorias formuladas. Pretendemos com esse trabalho, contribuir para novas reflexões acerca do tema em questão e mostrar a atualidade do socialismo científico, enquanto teoria revolucionária.

Este estudo está fundamentado nos pressupostos teóricos do materialismo histórico dialético, baseado nos escritos de Marx e obras de coautoria com Friedrich Engels, no conjunto de textos organizados pela Editora Paz \& Terra com o título Educação $e$ Emancipação ${ }^{2}$, de Theodor Adorno, além de bibliografias marxistas. Espera-se demonstrar que, embora Adorno tivesse em certa medida influências marxistas, principalmente na crítica à ideologia burguesa, sua visão no tocante ao objeto de análise citado difere da percepção marxiana $^{3}$, pois esta define a emancipação como a libertação real do indivíduo, em busca de sua verdadeira comunidade que é a essência humana.

\section{O PENSAMENTO E A MATÉRIA QUE PENSA}

A sociedade brasileira em pleno século XXI ainda vivencia inúmeras contradições econômicas, políticas e culturais. Basta observar as críticas ao nosso sistema educacional quando a mídia publica resultados dos nossos estudantes em avaliações baseadas nos parâmetros internacionais e ao mesmo tempo se exalta uma posição econômica do Brasil entre os dez primeiros lugares em nível mundial. No último ano, um dos ministérios que mais sofreu com cortes orçamentários ${ }^{4}$ foi o Ministério da Educação (MEC), além disso, diminui cada vez mais a procura dos jovens pela licenciatura e aumenta em número considerável a oferta de ensino superior privado. O que isso representa? Qual o papel da educação numa sociedade de classes?

Talvez esse trabalho, possa gerar algumas reflexões e trazer respostas para tais questionamentos. A escolha em utilizar como referências Marx, Engels e Adorno é justamente apontar que a crítica à sociedade burguesa pode ser aparentemente um elemento de uniformidade entre os teóricos, mas a partir de uma análise mais profunda pode revelar significativas contradições. Dessa forma, muitos podem ser críticos ao capitalismo, mas nem todos empregam suas forças manuais e mentais para sua extinção e "Até os políticos radicais e revolucionários já não procuram o fundamento do mal na essência do Estado, mas numa determinada forma de Estado, no lugar da qual eles querem colocar uma outra forma de Estado". (MARX, 1844, p. 7).

Sabemos que no modo de produção capitalista a emancipação expressa igualdade jurídica, além de liberdade e direito de propriedade, elementos fundamentais para a manutenção de um sistema dominado pelos interesses da classe burguesa. Dessa forma, esse 


\section{Revista HIIS'TEIDBR Dm-lime}

Artigo

doi: $10.20396 /$ rho.v17i4.8645854

pensamento está na contramão da teoria marxiana que defendia a superação da sociedade de classes para se alcançar a liberdade plena, integral e livre de contradições.

Refletir sobre educação e emancipação a partir dos pressupostos teóricos do materialismo histórico dialético representa um grande desafio para qualquer pesquisador. Primeiro, por ser necessário inserir o objeto na sua totalidade, integrado às diversas categorias que constituem a sociedade e em segundo lugar por acreditarmos que nosso estudo pode ser um importante elemento na direção do modo como pode se delinear uma práxis revolucionária, como nos atentou Marx e Engels (2002) na terceira tese sobre Feuerbach. São estas as condições objetivas que provocaram a problematização do assunto, na tentativa de não só resistir, contudo, manter-se na luta pela superação de um sistema que divide os indivíduos em classes, neutralizando suas potencialidades físicas e espirituais.

Para Marx e Engels (2002), o que os homens são coincidem com o que produzem e de que forma produzem, ou seja, as suas condições materiais de produção. Essas condições não são unicamente econômicas e sim as relações sociais entre as pessoas e os seus meios de existência a partir de um determinado modo de produção. O homem, nesse sentido, é o conjunto das relações sociais. Logo, as condições materiais e as relações sociais influenciam o pensamento dos sujeitos e, dessa maneira, as reflexões teóricas de Marx, Engels e Adorno estão diretamente ligadas ao contexto no qual viveram suas experiências.

Os teóricos Karl Marx (1818-83) e Friedrich Engels (1820-95) vivenciaram um contexto de muitas transformações nas relações de produção e de trabalho. A Europa no século XIX foi palco do capitalismo industrial, das lutas de trabalhadores por direitos políticos e sociais, da difusão dos ideais liberais e do desenvolvimento das correntes teóricas do Positivismo, Idealismo, Anarquismo, Socialismo Utópico e Científico. Influenciados pelo materialismo de Feuerbach e pela Dialética de Hegel, os dois pensadores avançaram no sentido de conceber as relações humanas a partir da realidade concreta e suas múltiplas determinações, acreditando que estas estariam em constante movimento ${ }^{5}$.

Tanto Marx, quanto Engels não se dedicaram somente a escrever obras de cunho político-filosófico, mas atuaram diretamente em organizações operárias, como a Liga dos Justos e a Liga dos Comunistas. A participação nesse movimento operário, que ultrapassava as barreiras nacionais, favoreceu uma escrita extremamente politizada, visto que é possível observar no conjunto de suas obras compreensões pormenorizadas do sistema capitalista; descrições da exploração do trabalho; apontamentos críticos à ideologia dominante; análises históricas; programas e direcionamentos revolucionários. Desse modo, faziam jus à crítica estabelecida aos filósofos que só interpretaram o mundo, porque, para ambos, a questão era transformá-lo. (MARX; ENGELS, 2002).

No século XIX o capitalismo industrial estava em pleno desenvolvimento e devido aos vários exílios, Marx pode constatar as condições precárias do proletariado, bem como sua resistência diante da exploração do trabalho. Do Ludismo ao Cartismo, da Primavera dos Povos à Comuna de Paris ${ }^{6}$, esse cenário colaborou na construção de análises econômicas, filosóficas e políticas. Marx e Engels, por exemplo, procuraram entender a organização do capitalismo industrial e, dessa forma, conceberam a humanidade em suas relações sociais concretas, ou seja, reais, pois estas condições materiais, em cada tempo e espaço, seriam responsáveis pela geração dos valores, pensamentos e formas jurídicas da sociedade. 


\section{Revista HIISTEIDBR On-lime}

Nessa conjuntura, se insere a crítica à sociedade burguesa e a exploração do trabalho, marcando a escrita desses dois pensadores. Como filósofos militantes propuseram a abolição dessa forma de organização social a fim de que a humanidade alcançasse a sua emancipação, pois "No lugar da velha sociedade burguesa, com suas classes e antagonismos de classes, surge uma associação na qual o livre desenvolvimento de cada um é a condição para o livre desenvolvimento de todos". (MARX; ENGELS, 2012, p. 69).

Na concepção marxiana, fica evidente a necessidade da supressão da propriedade burguesa para o nascimento de uma sociedade em que todos sejam realmente livres de qualquer forma de exploração, ou seja, emancipados. Nesse sentido, as teses de Marx e Engels constituem uma práxis revolucionária, pois visa transformar radicalmente a realidade, a fim de efetivar-se o socialismo.

No século XX, lideranças revolucionárias e pensadores construíram releituras das teses de Marx e Engels, conforme suas condições históricas. Citamos dois exemplos, devido a sua visibilidade no campo prático e teórico. Primeiramente as concepções de Vladimir Ilyich Ulyanov, mais conhecido como Lenin, e em segundo os integrantes da Escola de Frankfurt. As teorias de Lenin, denominado de marxismo-leninismo, tiveram grande influência nos movimentos proletários do mundo ocidental, inclusive no Brasil durante os anos democráticos de 1945-1964.

Em relação aos pensadores frankfurtianos, estes se posicionaram diante das novas contradições de sua época a partir da esfera crítica e reflexiva de viés marxista. Inferimos que essas duas correntes de pensamento, se assim podemos defini-las, marcaram de modo diferente os rumos da fundamentação marxista (teoria e prática) no decorrer do século XX, porém, nos concentraremos na última, devido ao objeto desta análise.

A Escola de Frankfurt surgiu em 1924 sob a luz da Teoria Crítica ${ }^{7}$ e foi bastante influenciada pelos acontecimentos das duas guerras mundiais e pelas mudanças ocorridas nas relações sociais com o avanço capitalista e sua indústria cultural ${ }^{8}$. Entre os frankfurtianos encontra-se o filósofo e sociólogo Theodor Adorno. Os escritos ora analisados e compilados na obra Educação e Emancipação, fazem parte dos debates e palestras, transmitidos pela rádio do Estado alemão Hessen entre os anos de 1959 e 1969. De maneira específica, o teórico se propôs discutir as questões educacionais com foco na Alemanha num período de Guerra Fria, além de pensar, de modo mais global, a educação no campo da formação cultural.

Embora a concepção de Adorno em relação à educação tenha influências marxistas, devido ao seu posicionamento crítico à sociedade burguesa, seus textos são marcados por referências kantianas ${ }^{9}$ e freudianas ${ }^{10}$. Sua reflexão político-social da educação emergiu de um contexto de agitações sociais da década de 1960, em que se destacam a expansão dos movimentos nacionalistas em regiões da chamada periferia econômica, a tentativa de renovação do socialismo soviético no Leste Europeu, a resistência de grupos estudantis e intelectuais frente ao modelo tradicional de ensino burguês e em especial a recuperação alemã das atrocidades da II Guerra Mundial.

Adorno, enquanto intelectual, vivenciou o florescimento da interpretação neomarxista e da psicologia nos institutos de pesquisas sociais europeus. Como alemão sofreu com as perseguições do Nazismo, exilando-se nos Estados Unidos da América, onde 


\section{Revista HIIS'TEIDBR Dm-lime}

entrou em contato com uma realidade econômica bem distinta do que estava habituado. No retorno à Alemanha, assumiu na década de 1950 a direção da Escola de Frankfurt e passou a centrar seu pensamento na questão da desbarbarização humana, uma vez que acreditava que os traços de barbárie, ainda visíveis na sociedade europeia, poderiam se repetir gerando novamente as experiências de Auschwitz ${ }^{11}$. Nesse sentido, o seu pensamento educacional é marcado pela defesa de uma democracia efetiva e pela noção de esclarecimento fundamentado no racionalismo.

Segundo a teoria marxiana, as ideias, as representações e a consciência é linguagem da vida real, ou seja, das ações materiais humanas, logo é fundamental verificar quais as condições concretas que levam os homens a pensarem de tal maneira e assim traçar uma investigação histórica, pois:

Em oposição à filosofia alemã, que desce do céu para a terra, aqui sobe-se da terra ao céu. Isto é, não se parte daquilo que os homens dizem, imaginam ou pensam nem do que são nas palavras, no pensamento, na imaginação e na representação dos outros, para chegar aos homens de carne e osso; parte-se dos homens, da sua atividade real. (MARX; ENGELS, 2002, p. 26).

O fato de Adorno ser músico, filósofo e sociólogo da Teoria Crítica, vivenciando uma democracia burguesa, o avanço do que se denominou de indústria cultural e o esfacelamento das experiências socialistas fez de suas abordagens sobre educação uma análise crítica da cultura de massa, tendo em vista a efetividade democrática. Enquanto, o fato de Marx e Engels, por exemplo, serem além de teóricos, militantes do Partido Comunista e terem uma reflexão econômica-social com foco nas condições do proletariado no modo de produção capitalista, possibilitaram que ambos compreendessem a emancipação na perspectiva da supressão da propriedade burguesa.

Diante desse pressuposto, analisaremos como os pensadores citados conceberam educação e emancipação, levando em consideração os contextos históricos nos quais estavam inseridos e suas críticas à sociedade da época. Além do mais, a intenção é demonstrar as contradições dos discursos e projetos em torno de uma educação para emancipação no sistema capitalista, com algumas menções à realidade brasileira a partir da teoria marxiana.

\section{EDUCAÇÃO PARA EMANCIPAÇÃO}

No dicionário de Filosofia, Nicola Abbagnano apresentou o conceito geral de Educação como sendo esta a transmissão e o aprendizado das técnicas culturais necessárias à sobrevivência humana. Segundo o verbete, a dimensão formadora e a relação entre educação e democracia marcaram as reflexões da pedagogia no século XX. Já em relação à Emancipação o mesmo foi descrito como um processo de libertação em que o indivíduo se desvincularia de qualquer dominação religiosa, política, econômica e etc. A exposição destacou que há variações na definição devido aos vários movimentos teóricos, embora, a ideia de emancipação seja própria da "modernidade" e de sua noção de progresso, frutos do movimento Iluminista. 


\section{Revista HIIST'FIDBR Dm-line}

Se no sentido lato a educação é fundamental à conservação das dimensões sociais, bem como a emancipação e a autonomia dos indivíduos, a análise que se segue pretendeu compreender como Marx, Engels e Adorno, em suas conjunturas econômicas, políticas e culturais, conceberam essa temática a fim de contribuir para a problematização do que se entende por Educação para Emancipação. Acreditamos ser este o caminho mais adequado para o historiador da educação, principalmente aquele que adota o referencial teóricometodológico do materialismo histórico dialético, pois ao valer-se de categorias de análise como a totalidade e a mediação, caracteriza seu objeto de estudo a partir das várias dimensões históricas.

\section{EDUCAÇÃO E EMANCIPAÇÃO EM MARX}

No livro Educação e Ensino na obra de Marx e Engels, Lombardi (2011) salientou que esses dois teóricos não desenvolveram estudos específicos acerca da educação, sendo que suas maiores contribuições estão presentes na análise que fizeram sobre o capitalismo. Portanto, a categoria educação está presente nas abordagens marxianas, quando se faz a crítica ao ensino burguês ou quando se propõe uma educação do proletariado no modo de produção capitalista. Já a categoria emancipação aparece na tese revolucionária de superação da propriedade burguesa.

Na concepção marxiana, o trabalho é o fundamento do ser social, pois o homem como um ser social se (re)produz pelo trabalho, o que assinala a produção da sua vida material. É preciso esclarecer essa noção para entender que a educação é uma das mediações do trabalho, e que embora a educação tenha papel fundamental no processo revolucionário ela não é capaz de isoladamente revolucionar as estruturas sociais, conforme algumas publicidades ideológicas contemporâneas que colocam as reformas educacionais como prioritárias e nem sequer levantam outras questões sociais, como, por exemplo, as condições básicas de sobrevivência.

Em um artigo publicado em 1844 no jornal alemão Avante!, Marx afirmou que "Para educar as crianças, é preciso alimentá-las e liberá-las da necessidade de trabalhar para viver. Alimentar e educar as crianças abandonadas, isto é, alimentar e educar todo o proletariado que está crescendo, significaria eliminar o proletariado e o pauperismo". (MARX, 1844, p. $7)$.

Atualmente, o Estado e as entidades privadas brasileiras, apesar de utilizarem discursos e ações visando uma educação para todos, não tem como objetivo real a consolidação desse projeto, pois, se isso ocorresse conforme, o pensamento marxiano, os dois setores precisariam propor a extinção do sistema que gera a divisão da sociedade em classes antagônicas, a pobreza e a sua própria existência. Logo, o Estado e as entidades privadas, não iriam destruir a si mesmo, portanto, não atacam o germe dos males sociais, se ocupando de medidas de caráter administrativo e assistencialista.

Na sociedade capitalista, em que vigora a divisão das classes e a divisão do trabalho, o proletariado perdeu sua autonomia, sua livre criação e poder de domínio no processo de fabricação dos bens de consumo, tornando-se "[...] mero acessório da máquina, do qual se exige apenas o mais simples e monótono movimento da mão, de aprendizado facílimo". 
Artigo

doi: $10.20396 /$ rho.v17i4.8645854

(MARX; ENGELS, 2012, p. 51). Essa unilateralidade faz da educação a expressão das contradições nas lutas de classes, pois:

Logo que o trabalho começa a ser distribuído, cada um passa a ter um campo de atividade exclusivo e determinado, que lhe é imposto e ao qual não pode escapar; o indivíduo é caçador, pescador, pastor ou crítico, e assim deve permanecer se não quiser perder seu meio de vida. (MARX; ENGELS, 2007, p. 37-38).

Segundo Dangeville (1978), essa divisão social do trabalho acaba por criar uma fração de extrema diferenciação entre atividade intelectual e material, cabendo ao proletariado um nível de cultura deveras medíocre no regime assalariado. Mas, apesar das precárias condições de trabalho, da ausência de efetividade de legislação educacional aos operários e de representação política no século XIX, o próprio capitalismo faz emergir trabalhadores que "[...] por educação, tradição, costume, reconhece as exigências daquele modo de produção como leis naturais evidentes". (MARX, 1996, p. 358).

Portanto, a educação na sociedade burguesa, segundo a teoria de Marx e Engels, nada mais é que a transmissão de valores burgueses, uma vez que os pensamentos da classe dominante são os pensamentos dominantes. Pois, a classe que possui o poder material também possui o comando dos meios de produção intelectual e para manter seu poderio precisa representar seus interesses como sendo absolutos e legítimos.

Mas se de um lado o capitalismo industrial é sinônimo de unilateralidade, devido à especialização dos ofícios, por outro lado o seu desenvolvimento cria as condições para uma formação educacional mais integrada e técnica, por causa das exigências tecnológicas do mercado. Na obra $O$ Capital, Marx aponta essa contradição presente no desenvolvimento do modo de produção capitalista:

\begin{abstract}
Ela torna uma questão de vida ou morte substituir a monstruosidade de uma miserável população trabalhadora em disponibilidade, mantida em reserva para as mutáveis necessidades de exploração do capital, pela disponibilidade absoluta do homem para as exigências variáveis do trabalho; o indivíduo-fragmento, o mero portador de uma função social de detalhe, pelo indivíduo totalmente desenvolvido, para o qual diferentes funções sociais são modos de atividade que se alternam. (MARX, 1996, p. 115-116).
\end{abstract}

A grande indústria diante da necessidade de sobrevivência no processo de desenvolvimento do capitalismo precisa de trabalhadores mais versáteis e essa instrução mais elaborada, ofertada pelas escolas de ensino profissional, pode produzir, segundo Marx o germe de uma educação voltada para o desenvolvimento das várias dimensões humanas, colaborando no processo revolucionário. Pois, o "[...] desenvolvimento das contradições de uma forma histórica de produção é, no entanto, o único caminho histórico de sua dissolução e estruturação de uma nova". (MARX, 1996, p. 116).

Por educação, Marx (1866) definiu o desenvolvimento mental e físico e a instrução tecnológica, pois segundo sua concepção a combinação dessas dimensões elevaria o operariado acima do nível da classe média e superior. Na obra Crítica do Programa de Gotha, a união entre trabalho produtivo ${ }^{12}$ com ensino, desde a infância, aparece como um poderoso meio de transformação social. Para Marx (2012), as escolas de ensino profissional, teóricas e práticas, poderiam ser combinadas com a escola pública, além disso, não caberia 
ao Estado o papel de educador do povo, tirando qualquer forma de influência do governo e da igreja na educação dos indivíduos.

Para Marx, somente na sociedade comunista o homem terá uma educação plena, capaz de desenvolver totalmente suas potencialidades, pois nessa nova organização social os entraves que impediam a emancipação humana estariam abolidos. Dessa maneira, o conceito marxiano de emancipação está diretamente relacionado ao processo de uma efetiva liberdade onde as lutas de classe, a divisão do trabalho e a propriedade privada dos meios de produção não mais existiriam. Emancipar-se não se trata somente de autonomia política, mas, sobretudo voltar-se à natureza humana, eliminando toda e qualquer forma de dominação econômica e suas frações políticas e culturais.

A emancipação humana só será plena quando o homem real e individual tiver em
si o cidadão abstracto; quando como homem individual, na sua vida empírica, no
trabalho e nas suas relações individuais, se tiver tornado um ser genérico; e quando
tiver reconhecido e organizado as suas próprias forças (forces propres) como
forças sociais, de maneira a nunca mais separar de si esta força social como força
política. (MARX, 1843, p. 30 ).

A emancipação do homem nada mais é que um processo de libertação do modo de produção capitalista que o desumaniza, ao mesmo tempo é um processo histórico, pois ao se apropriar da totalidade existente das forças produtivas, o proletariado ${ }^{13}$ além de atingir o seu eu, pode garantir sua existência e desenvolver integralmente suas aptidões e seus sentidos. Dessa maneira, a contradição entre trabalho intelectual e manual só será suprimida na sociedade comunista, porque nesta, o trabalho tornar-se-á a primeira necessidade vital e o princípio de cada um segundo suas capacidades, a cada um segundo suas necessidades se transformará em realidade. (MARX, 2012, p. 32).

No que diz respeito à emancipação, Marx distinguiu-a em emancipação política e emancipação humana, apresentando os limites da primeira em relação à segunda, pois a primeira forma admite a liberdade do homem no âmbito da sociedade civil, mas não a liberdade concreta do homem.

A emancipação política representa, sem dúvida, um grande progresso. Não constitui, porém, a forma final de emancipação humana, antes é a forma final de emancipação humana dentro da ordem mundana até agora existente. Nem vale a pena dizer que estamos aqui a falar da emancipação real, prática. (MARX, 1843, p. 14-15).

A partir da teoria marxiana, podemos inferir que a educação para emancipação é uma condição para a revolução liderada pela classe proletária, possibilitando uma nova organização social onde não haverá predomínio das relações de classe e da propriedade privada. A superação das contradições da sociedade capitalista é o objetivo dessa educação voltada à plena liberdade, momento em que homem não mais será mercadoria de outro e como homem novo e total desenvolver-se-á suas múltiplas faculdades. Educar para emancipação é uma práxis revolucionária, pois é ao mesmo tempo formar indivíduos para viver conforme sua essência, ou seja, no conjunto das relações sociais sem interferências exteriores, como nos aponta Marx e Engels: 


\section{Revista HIIS'TEIDBR On-line}

[...] na sociedade comunista, onde cada um não tem um campo de atividade exclusivo, mas pode aperfeiçoar-se em todos os ramos que lhe agradam, a sociedade regula a produção geral e me confere, assim, a possibilidade de hoje fazer isto, amanhã aquilo, de caçar pela manhã, pescar à tarde, à noite dedicar-me à criação de gado, criticar após o jantar, exatamente de acordo com a minha vontade, sem que eu jamais me torne caçador, pescador, pastor ou crítico. (2007, p. 38).

Embora o germe dessa educação possa nascer das contradições da sociedade burguesa, esta é incapaz de promover uma educação para a emancipação, conforme a perspectiva de Marx e Engels, pois, para Roger Dangeville (1978) a desigualdade social gera desigualdade de conhecimento e a burguesia utiliza de mecanismos como os meios de comunicação, o Estado e a escola para mistificar e conservar seu status quo, impedindo assim que a classe mais espoliada conheça profundamente a realidade para então modificála.

Essa exposição teórica nos permite entender que a real libertação do indivíduo, ou seja, a emancipação humana só pode ser consolidada a partir do momento em que a humanidade tenha resolvido seus problemas mais básicos, como comer, vestir e morar. Pois, o primeiro ato histórico é a produção dos meios para satisfazer essas necessidades, segundo os pressupostos marxianos. Assim, para efetivar uma educação com vistas à formação integral do ser humano é preciso exterminar a fome e a falta de habitação, por exemplo, o que é impossível com a manutenção do modo de produção capitalista alicerçado na concentração de capital e na exploração do trabalho.

Logo, a consolidação de uma nação desenvolvida, compreendendo esta como uma sociedade sem nenhum tipo de opressão e injustiça social, depende primeiramente da destruição do sistema gerador da exploração e das desigualdades sociais, ou seja, do modo de produção capitalista. Como a existência da classe burguesa e seu Estado representativo depende da manutenção desse sistema de produção, obviamente persistem em projetar reformas superficiais e não em mudanças estruturais, por isso não há como esperar outro comportamento por parte desses dirigentes.

\section{EDUCAÇÃO E EMANCIPAÇÃO EM ADORNO}

O filósofo Theodor Adorno, centralizou a questão da Educação e Emancipação na realidade alemã no pós II Guerra Mundial, primeiramente devido suas experiências, e por fim, segundo suas próprias palavras, porque foi na Alemanha que ocorreu a mais trágica manifestação de barbárie de todos os tempos. Para analisar sua concepção educacional é fundamental conceituar barbárie e desbarbarização, uma vez que essas expressões estão diretamente relacionadas à sua reflexão sociológica.

Adorno vivenciou na Alemanha o florescimento do Nazismo e, consequentemente, às perseguições da Polícia Secreta do Estado (GESTAPO) aos intelectuais considerados opositores políticos. Logo, exilou-se na Inglaterra e depois nos Estados Unidos da América, retornando ao seu país somente na década de 1950, quando sobraram aos alemães, além da restauração econômica da nação, a reconstrução da memória histórica marcada pela 
brutalidade cometida pelo III Reich nos campos de concentração. A barbárie possui fatores psicológicos e objetivos e assim foi definida:

\begin{abstract}
Entendo por barbárie algo muito simples, ou seja, que, estando na civilização do mais alto desenvolvimento tecnológico, as pessoas se encontrem atrasadas de um modo peculiarmente disforme em relação a sua própria civilização — e não apenas por não terem em sua arrasadora maioria experimentado a formação nos termos correspondentes ao conceito de civilização, mas também por se encontrarem tomadas por uma agressividade primitiva, um ódio primitivo ou, na terminologia culta, um impulso de destruição, que contribui para aumentar ainda mais o perigo de que toda esta civilização venha a explodir, alias uma tendência imanente que a caracteriza. (ADORNO, 1995, p. 155).
\end{abstract}

A barbárie é assinalada pela irracionalidade, pois a agressão física primitiva representa a explosão de uma violência deformada, no sentido de ser incoerente com princípios fundamentados na razão. Adorno destacou, por exemplo, que uma rebelião estudantil não corresponde a uma ação de barbárie, devido à sua justificativa política refletida pelos revoltosos. Porém, quando "[...] um time de fora que vence é ofendido e agredido num estádio, ou quando um grupo de presumíveis bons cidadãos agride estudantes ainda que só mediante palavras" (1995, p. 160) estes atos seriam alguns exemplos de barbárie. Percebe-se que esta ação não é somente a hostilidade física e sim toda e qualquer crueldade incoerente, amostra proporcionada pelo Nazismo e que assinalou a escrita dos pesquisadores da Escola de Frankfurt.

Para Adorno, a desbarbarização é a finalidade mais premente da educação. Não é somente suprimir a agressão e sim trabalhar para exterminar toda a forma de domínio irracional, especialmente nos primeiros anos de vida. A chave dessa transformação é a relação entre sociedade e escola, uma vez que esta instituição poderia despertar a consciência dos estudantes, permitindo que realizem uma crítica permanente do decorrer de sua vida. Todavia, como teórico crítico, interpretou a escola na sociedade burguesa como protótipo de alienação social, pois a ordem econômica vigente impõe à maior parte das pessoas a impotência diante de relações determinadas.

A educação, segundo a concepção de Adorno, tem um papel fundamental para evitar que se repita a barbárie, por conseguinte, ela possui um papel político de extrema importância para o êxito da emancipação, permitindo a consolidação de uma democracia em que os indivíduos possam ser capazes de refletir sobre a realidade, livre de determinações externas ao seu eu. Na democracia o antidemocrata seria o sujeito avesso à consciência independente, ou seja, do pensamento livre e particular das pessoas.

Na perspectiva de Adorno, a educação para a emancipação é esclarecimento e nesse sentido a influência de Kant é visível, pois a saída da menoridade e a conquista da liberdade, ou seja, a busca pela autonomia de orientar-se por si mesmo são elementos que permeiam sua concepção. Educar os indivíduos não é modelá-los a partir de elementos extrínsecos e muito menos a transmissão de conhecimentos, mas sim, "[...] a produção de uma consciência verdadeira" (ADORNO, 1995, p. 141) a fim de construir uma democracia efetiva. Para esse teórico, a educação, e seria até mais adequado utilizar a expressão educação política devido a sua proposta de conscientização, só tem sentido quando se dirige a uma autorreflexão 
crítica. Exemplos de como pode ocorrer isso na instituição escolar são descritos da seguinte maneira:

[...] imaginaria que nos níveis mais adiantados do colégio, mas provavelmente
também nas escolas em geral, houvesse visitas conjuntas a filmes comerciais,
mostrando-se simplesmente aos alunos as falsidades aí presentes; e que se proceda
de maneira semelhante para imunizá-los contra determinados programas matinais
ainda existentes nas rádios, em que nos domingos de manhã são tocadas músicas
alegres como se vivêssemos num "mundo feliz", embora ele seja um verdadeiro
horror; ou então que se leia junto com os alunos uma revista ilustrada, mostrando-
lhes como são iludidas, aproveitando-se suas próprias necessidades impulsivas; ou
então que um professor de música, não oriundo da música jovem, proceda a
análises dos sucessos musicais, mostrando-lhes por que um hit da parada de
sucessos é tão incomparavelmente pior do que um quarteto de Mozart ou de
Beethoven ou uma peça verdadeiramente autêntica da nova música. (ADORNO,
1995, p. 183).

A concepção de emancipação, por esse viés teórico, é a libertação do indivíduo das relações que são alheias à natureza humana, relações estas baseadas na contradição social e na heteronomia, ou seja, na sujeição de uma vontade externa. Embora, Adorno apresente esses entraves, o mesmo não centralizou sua reflexão nas barreiras econômicas que impediam essa conquista de autonomia, mas colocou em pauta a possibilidade de uma educação para a contradição e resistência, que em sua opinião concretizaria uma eficiente emancipação. Vale lembrar que sua reflexão é política e social e influenciada pela psicologia de Sigmund Freud, principalmente no que diz respeito à inclinação humana à barbárie por meio de experiências culturais.

Se o homem emancipado é uma condição para uma democracia plena e a sociedade atual mantém o homem não emancipado, conforme o pensamento de Adorno, então a democracia atual é limitada. Pois, as pessoas possuem direitos políticos, mas ao mesmo tempo representativos e além do mais, elas são dominadas por forças externas, gerando a incapacidade de conhecerem a verdadeira realidade e suas causas. Dessa maneira, é possível inferir que apesar da família e das instituições promoverem atualmente uma educação fundamentada na resistência e na contradição, a educação se limitará a formar sujeitos críticos numa sociedade em que ainda prevalecerão as condições materiais que geraram a barbárie.

Adorno admitiu o papel importante da escola na formação de uma consciência crítica, mas ao mesmo tempo afirmou que a organização econômica vigente impõe impotência, por meio da alienação social, à maioria das pessoas. A partir dessa lógica de pensamento, inferimos que por mais que educação escolar tenha esse compromisso de conscientização, ela não é capaz de sozinha enfrentar a resistência do sistema capitalista à politização da classe trabalhadora. Além do mais, a própria estrutura educacional institucionalizada é (re)construída para atender as demandas do capitalismo, pois é elaborada pelo Estado burguês em prol da classe burguesa.

Um exemplo concreto para compreender melhor os limites de uma educação para a emancipação, enquanto autonomia crítica, na sociedade de classes é o caso brasileiro da reforma do Ensino Médio, proposta pelo MEC e sancionada pelo atual presidente, Michel Temer, em 2017. A oferta do ensino integral com eixos formativos justificou-se pela necessidade de melhorar o Índice de Desenvolvimento da Educação Básica (IDEB) e deixar 
mais atrativo esse nível de escolaridade aos adolescentes. Na propaganda veiculada na mídia, a mensagem apontou para a conquista da liberdade do jovem em decidir seu próprio futuro. Um futuro que certamente não é aquele projetado por Adorno de crítica à sociedade burguesa e autonomia individual, e muito menos por Marx e Engels de erradicação de toda forma de opressão.

Observamos, nessa reforma, mais uma vez o subterfúgio estatal de não enfrentamento dos males sociais. Pois, se as condições históricas determinam que os adolescentes pobres trabalhem para ajudar na renda familiar a fim de comer, vestir e morar, como eles poderiam ficar na escola integralmente? E por que reformar inicialmente o ensino médio que é o estágio entre o fundamental e o nível superior? Para obter as respostas basta saber que do ponto de vista político o Estado é o ordenamento da sociedade e como tal não pode eliminar as contradições entre os interesses gerais e os interesses privados, "[...] sem eliminar a si mesmo, uma vez que repousa sobre essa contradição". (MARX, 1844, p. 8).

\section{CONSIDERAÇÕES FINAIS}

Ainda que Marx e Engels não tenham se dedicado exclusivamente à questão educacional, suas teorias estão baseadas na perspectiva da classe operária. Nesse sentido, o debate que realizaram partiu de uma análise concreta da educação e do ensino através da divisão do trabalho na sociedade capitalista, o que acaba por trazer à tona a desigualdade de conhecimento alinhada à desigualdade social. Em seus escritos, referenciaram a educação de modo geral, defendendo a ideia de que esta deva partir da prática e da sensibilidade da criança, unindo-se o campo intelectual com a produção material.

A divisão do trabalho, intrínseca ao modo de produção capitalista, caracteriza o fio condutor da discussão acerca da educação e do ensino proposta por esses pensadores. Neste contexto, os saberes e a ciência passam a ser propriedade do capital e interferem no desenvolvimento do indivíduo, pois contribuem para a manutenção do antagonismo entre as classes sociais. Esses autores preconizam não uma mudança reformista e direcionada somente à dimensão educacional, e sim, uma alteração radical no horizonte histórico no qual é imprescindível que desapareçam as relações de dominação entre as classes. O projeto de educação está diretamente ligado a um projeto social revolucionário, pois são os homens que transformam as circunstâncias e o próprio educador precisa ser educado. Logo, o mundo precisa ser transformado e não contemplado. (MARX; ENGELS, 2002).

Segundo Marx (1844), somente uma transformação radical na estrutura econômicosocial, por meio de uma revolução geral - social e política-, pode dissolver as velhas relações sociais. Nesse sentido, acreditamos que junto com a derrocada da antiga ordem a velha educação também é derrotada. A partir de então, o homem poderá reencontrar consigo mesmo, ou seja, na sua essência e assim nascerá o homem emancipado, cuja totalidade será sua principal característica, podendo mover-se por diferentes campos de atuação, desenvolvendo assim suas infinitas capacidades intelectuais, físicas e espirituais.

De maneira distinta, Theodor Adorno não frisa a superação do sistema capitalista e sim da democracia limitada. Sua reflexão não é materialista, histórica e dialética e sim uma análise política e social, a partir da teoria crítica, o que contribuiu para conceber a educação 
para emancipação como uma formação voltada para o esclarecimento das contradições existentes no seio da sociedade burguesa e para a resistência do porvir da barbárie. Não temos dúvida de que o Nazismo representou uma forma irracional de agressão, mas não seria também o capitalismo uma agressividade primitiva? Um impulso de destruição da humanidade, por meio da irracionalidade burguesa em concentrar riquezas provocando guerras, miséria e a morte física e espiritual da grande massa populacional em nome da civilização e do progresso?

Quase um século separa os escritos de Marx, Engels e Adorno, anos de muitas transformações no modo de produção capitalista. No século XIX, a tecnologia voltava-se para o aperfeiçoamento das máquinas e da exploração da energia; a burguesia ainda lutava para se manter nos espaços políticos com o esfacelamento de monarquias e impérios e buscava controlar os mercados de compra e venda; a legislação trabalhista ainda era irrisória frente às precárias condições de trabalho. Já na segunda metade do século XX a sociedade vivenciou a expansão do capital para vários setores, entre eles, a cultura. As expressões artísticas tornaram-se mercadorias com a indústria cultural; a ideologia burguesa ampliou o número de sectários e a deformação do comunismo, pelas nações ditas socialistas, retardaram a concretização do último clamor do Manifesto do Partido Comunista.

As teorias de Marx, Engels e Adorno são frutos de suas atividades objetivas, pois "[...] não é a consciência que determina a vida, é a vida que determina a consciência". (MARX; ENGELS, 2002, p. 26). Sendo assim, este estudo não pretendeu centralizar os esforços em contrapor as concepções dos teóricos, isso seria até anacrônico, uma vez que o objetivo foi analisar os conceitos de Educação e Emancipação à luz do contexto histórico de cada um, orientado pelos pressupostos do materialismo histórico dialético. Contudo, é preciso destacar criticamente algumas diferenças entre os dois pensadores.

Para Marx (2012), a combinação entre trabalho produtivo e instrução desde a infância era concebida na sua época como um poderoso instrumento de transformação social. E ao se referir à emancipação, designou-a como a abolição de todo domínio de classe, luta esta liderada pela classe trabalhadora e que para consolidar-se seria necessária que em todas as nações modernas ocorresse uma confluência entre a prática e a teoria. Para Adorno, a educação é a produção de consciência e esclarecimento, necessidade de impedir o retorno de brutalidades como a de Auschwitz e já emancipação é a capacidade do indivíduo de conhecer a realidade sem submissões, levando-o à crítica e a resistência na sociedade atual.

Adorno não coloca a necessidade de supressão do modo de produção capitalista para se alcançar a emancipação, pois para este filósofo, com fortes influências do idealismo transcendental kantiano, a autonomia se revela no esclarecimento do ser, ou seja, no campo individual do sujeito. Em contrapartida, Marx e Engels considera a revolução como fator indispensável rumo a uma nova forma de sociedade em que não prevaleceria a distinção econômica e cuja emancipação fosse à aquisição de liberdade da classe proletária, extinguindo toda a barbárie de exploração humana cometida pelo capitalismo. Dessa maneira, salientamos que uma educação para a emancipação, conforme nos aponta Adorno só poderá criar indivíduos críticos e resistentes, porém, ainda que tenham esclarecimentos acerca da realidade seriam meros sujeitos politizados e não efetivamente emancipados, enquanto seres coletivos e totalmente desenvolvidos. 
No entanto, é perceptível uma aproximação conceitual entre ambos. Na medida em que Marx e Engels tematizam a emancipação humana na perspectiva da superação das contradições econômicas de dominação de classe, eles postulam a negação de toda e qualquer forma de tutela sobre a consciência humana, pois o comunismo, por exemplo, criaria condições para uma sociedade autêntica, onde não haveria mais uma dicotomia entre uma classe que pensa e outra que trabalha. A autenticidade humana estaria fundada sobre as bases do trabalho consciente, atividade emancipada, pois não haveria relação de estranhamento entre o resultado do trabalho e o ser do próprio trabalhador, portanto, alienação. O papel da revolução, neste sentido, seria esclarecedor, pois, ao iniciar o processo revolucionário, o proletariado não esclarece a si mesmo, mas também esclarece a classe dominante sobre a obscuridade desumana de sua dominação. A crítica, assim, seria o elemento unificador para a prospecção de uma sociedade emancipada, elemento comum tanto para Marx e Engels, como para Adorno.

Refletir sobre o tema Educação para a Emancipação na atualidade é problematizar em que direção pesquisadores e educadores desejam caminhar. A democracia burguesa continua mistificando concepções acerca da educação e uma delas é o ensino como promoção social, parafraseando Dangeville (1978). Se como educadores almejamos uma formação integral do sujeito, capaz de permitir o desenvolvimento de suas múltiplas capacidades e de alcançar sua verdadeira comunidade, que como vimos é a essência humana, é imprescindível lançar mão do senso comum e de frases estereotipadas sobre Educação e Emancipação e teorizar o sentido desses conceitos, com ênfase nas contradições do modo de produção capitalista e do ponto de vista do indivíduo real. Além disso, é fundamental a partir dos pressupostos marxianos a convergência entre teoria e prática, pois sendo trabalhadores do setor educacional precisamos agir como educadores e militantes, em prol de uma sociedade que a liberdade seja real, plena e efetiva e não uma aparência legal.

\section{REFERÊNCIAS}

ABBAGNANO, N. Dicionário de filosofia. 6. ed. São Paulo: WMF Martins Fontes, 2012.

ADORNO. T. W. Educação e emancipação. São Paulo: Paz \& Terra, 1995.

BOTTOMORE, T. Dicionário do pensamento marxista. 2. ed. Rio de Janeiro: Zahar, 2012.

DANGEVILLE, R. Apresentação. In: MARX, K.; ENGELS, F. Crítica da educação e do ensino. Introdução e Notas de Roger Dangeville. Lisboa: Moraes, 1978. p. 09-49.

FREUD, S. O futuro de uma ilusão. O mal-estar na civilização e outros trabalhos. v. XXI (1927-1931). Rio de Janeiro: Imago, 1969.

HORKHEIMER, M. Filosofia e teoria crítica e teoria tradicional e teoria crítica. In: BENJAMIN, W. et al. Textos Escolhidos. São Paulo: Abril Cultural, 1975. 
KANT, I. Resposta à pergunta: "o que é iluminismo". 1784. Tradutor Artur Morão. Disponível em: < http://www.lusosofia.net/textos/kant_o_iluminismo_1784.pdf>. Acesso em: 18 out. 2017.

LOMBARDI, J. C. Educação e ensino na obra de Marx e Engels. Campinas, SP: Alínea, 2011.

MARX, K. A Questão Judaica. 1843. Disponível em: <http://www.lusosofia.net/textos/ marx_questao_judaica.pdf >. Acesso em: 07 fev. 2016.

MARX, K. Crítica do programa de Gotha. São Paulo: Boitempo, 2012.

MARX, K. Glosas críticas marginais ao artigo: "o rei da Prússia e a reforma social". De um Prussiano. 1844. Tradução Ivo Tonet. Disponível em: <http://www.dominiopublico. gov.br/download/texto/ma000012.pdf>. Acesso em: 11 out. 2017.

MARX, K. Instruções para os delegados do Conselho Geral Provisório: as diferentes questões. 1866. Disponível em: <https://www.marxists.org/portugues/marx/1866/08 /instrucoes.htm\#n41>. Acesso em: 07 fev. 2016.

MARX, K. Manuscritos econômicos de Marx de 1861 a 1863. Parte 3. 1863. Disponível em: <http://www.histedbr.fe.unicamp.br/acer_fontes/acer_marx/tme_01.pdf >. Acesso em: 07 fev. 2016.

MARX, K. O Capital: crítica da economia política. Livro 1, tomo 2. São Paulo: Nova Cultural, 1996.

MARX K.; ENGELS, F. A Ideologia alemã, $1^{0}$ capítulo: seguido das teses sobre Feuerbach. São Paulo: Centauro, 2002.

MARX K.; ENGELS, F. A ideologia alemã: crítica da mais recente filosofia alemã em seus representantes Feuerbach, B. Bauer e Stirner, e do socialismo alemão em seus diferentes profetas (1845-1846). São Paulo: Boitempo, 2007.

MARX K.; ENGELS, F. Manifesto do partido comunista. São Paulo: Penguin Classics; Companhia das Letras, 2012.

ROUSSEFF, Dilma. Discurso da Presidenta da República, Dilma Rousseff, durante Compromisso Constitucional perante o Congresso Nacional. Brasília: Congresso Nacional, 01 jan. 2015. Disponível em: <http://www2.planalto.gov.br/acompanhe-o-planalto/discursos/ discursos-da-presidenta/discurso-da-presidenta-da-republica-dilma-rousseff-durantecompromisso-constitucional-perante-o-congresso-nacional-1>. Acesso em: 03 nov. 2017.

STALIN, J. V. Sobre o materialismo dialético e o materialismo histórico. 1938.

Disponível em: <https://www.marxists.org/portugues/stalin/1938/09/mat-dia-hist.htm>. Acesso em: 10 out. 2017. 


\section{Notas}

${ }^{1}$ Professora de História do Instituto Federal do Paraná, Campus Irati, PR. Doutoranda do Programa de PósGraduação em Educação da UEPG, PR. Pesquisadora do Grupo HISTEDBR - Campos Gerais. E-mail: carla.ramos@ifpr.edu.br

2 Temos conhecimento que o pensamento de Adorno sobre a Educação não está concentrado na publicação Educação e Emancipação (1995), porém, utilizamos neste artigo somente essa referência devido à concentração de ideias sobre a temática.

${ }^{3} \mathrm{O}$ termo marxiano é empregado nesse estudo, como referente aos conceitos e teorias presentes na produção intelectual-militante de Karl Marx e Friedrich Engels.

${ }^{4}$ Cf: http://economia.estadao.com.br/noticias/geral,educacao-e-o-ministerio-mais-atingido-com-ajuste-fiscal , 1617255 .

${ }^{5}$ É importante ressaltar que Marx e Engels não empregaram o termo materialismo histórico dialético. Sobre essa terminologia e outras denominações como Materialismo Filosófico, Materialismo Dialético e Materialismo Histórico, recomenda-se a leitura dos verbetes do Dicionário do Pensamento Marxista (BOTTOMORE, 2012) e a obra Sobre o Materialismo Dialético e o Materialismo Histórico (STÁLIN, 1938).

${ }^{6}$ Durante o século XIX alguns países da Europa Ocidental vivenciaram movimentos sociais de trabalhadores. Entre eles, citamos o Ludismo, uma revolta dos operários ingleses, ocorrida entre os anos de 1811-1812 contra as relações de trabalho ditadas pelo avanço tecnológico e industrial, resultando na destruição de máquinas. Também o Cartismo, um movimento mais amplo que marcou as décadas de 1830 e 1840 na Inglaterra, momento em que os operários organizaram manifestações, entre elas uma carta dirigida ao Parlamento exigindo mudanças políticas que beneficiariam sua classe. Já a Primavera dos Povos pode ser definida como uma onda de movimentos ocorridos na Europa devido à crise econômica e governos autoritários, nesse cenário os trabalhadores lutavam por melhores condições de vida e os burgueses por uma democracia liberal. Enfim, a Comuna de Paris (1871) considerada pela historiografia como a primeira experiência de governo proletário.

${ }^{7}$ Sobre essa teoria ler Horkheimer (1975).

${ }^{8}$ O termo "indústria cultural" foi utilizado por Adorno em seus estudos quando este se propôs a estudar os novos padrões da arte na lógica industrial.

${ }^{9}$ Sobre as contribuições de Kant para uma reflexão mais aprofundada acerca dos conceitos de liberdade, autonomia e emancipação, indicamos a leitura do texto Resposta à pergunta: “O que é o Iluminismo? ”, de sua autoria.

${ }^{10}$ Para aprofundamento do pensamento freudiano sobre liberdade, indicamos a leitura da obra $O$ futuro de uma ilusão. O mal-estar na civilização e outros trabalhos (FREUD, 1969).

${ }^{11}$ Auschwitz foi um conjunto de campos de concentração para abrigar judeus, construídos pelo regime Nazista na Polônia e representa um dos maiores símbolos do holocausto durante a segunda guerra mundial.

12 Por trabalho produtivo Marx define "[...] todo trabalho que produz alguma coisa, um resultado qualquer", diferentemente do trabalho produtivo no sistema de produção capitalista, que consiste no "[...] trabalho que produz o próprio produto como capital”. (MARX, 1863).

${ }^{13}$ Para Marx e Engels a classe proletária é a classe com maior potencial revolucionário e a apropriação das forças produtivas por essa classe só será realizada por meio de uma revolução.

Submetido em: 30/04/2016

Aprovado em: 16/09/2017 